\title{
Differences in Fusarium Species in brown midrib Sorghum and in Air Populations in Production Fields
}

\author{
Deanna L. Funnell-Harris, † Erin D. Scully, Scott E. Sattler, Roy C. French (retired), Patrick M. O’Neill, \\ and Jeffrey F. Pedersen (retired)
}

First, fourth, and fifth authors: Wheat, Sorghum and Forage Research Unit (WSFRU), United States Department of Agriculture-Agricultural Research Service (USDA-ARS), 251 Filley Hall, Department of Plant Pathology, University of Nebraska (UNL), Lincoln 68583-0937; second author: Stored Product Insect and Engineering Research Unit, USDA-ARS Center for Grain and Animal Health Research, Department of Entomology, Kansas State University, 1515 College Avenue, Manhattan 66502; and third and sixth authors: WSFRU, USDA-ARS, Departments of Agronomy and Horticulture, UNL.

Accepted for publication 5 July 2017.

\begin{abstract}
Several Fusarium spp. cause sorghum (Sorghum bicolor) grain mold, resulting in deterioration and mycotoxin production in the field and during storage. Fungal isolates from the air (2005 to 2006) and from leaves and grain from wild-type and brown midrib (bmr)-6 and bmr12 plants (2002 to 2003) were collected from two locations. Compared with the wild type, bmr plants have reduced lignin content, altered cell wall composition, and different levels of phenolic intermediates. Multilocus maximumlikelihood analysis identified two Fusarium thapsinum operational taxonomic units (OTU). One was identified at greater frequency in grain and leaves of $b m r$ and wild-type plants but was infrequently detected in air.

Nine $F$. graminearum OTU were identified: one was detected at low levels in grain and leaves while the rest were only detected in air. Wright's $F$ statistic $\left(F_{S T}\right)$ indicated that Fusarium air populations differentiated between locations during crop anthesis but did not differ during vegetative growth, grain development, and maturity. $F_{S T}$ also indicated that Fusarium populations from wild-type grain were differentiated from those in bmr6 or bmrl2 grain at one location but, at the second location, populations from wild-type and bmr6 grain were more similar. Thus, impairing monolignol biosynthesis substantially effected Fusarium populations but environment had a strong influence.
\end{abstract}

Grain mold disease, a major constraint to sorghum (Sorghum bicolor (L.) Moench) production throughout the world (Sharma et al. 2011), most likely occurs following infection of flowers and developing grain by airborne spores (asexual or sexual) (Bandyopadhyay et al. 1991; Denis and Girard 1980; Navi et al. 2005; Tarekegn et al. 2006). Sorghum grain mold disease results in reduced quality of grain harvested from the plant, and can cause rapid deterioration in storage (Audilakshmi et al. 2011; Castor and Frederiksen 1982; Navi 2006).

Numerous fungal species belonging to several genera (e.g., Alternaria, Cochliobolus, Fusarium, and Leptosphaeria) have been reported as causative agents of grain mold (Funnell-Harris et al. 2013b; Navi et al. 2005; Tarekegn et al. 2006). Fusarium spp. that are members of the Fusarium fujikuroi species complex are common in grain crops (Alves dos Reis et al. 2010; Boutigny et al. 2012; Funnell-Harris et al. 2010b; Han et al. 2014; Sreenivasa et al. 2008). Other Fusarium spp. such as F. anthophilum (A. Braun) Wollenw. 1916, F. nelsonii Marasas \& Logrieco 1998, F. sporotrichioides Sherb. 1915, F. graminearum Schwabe 1839 (synonym Gibberella zeae (Schwein.) Petch 1936), and members of the F. incarnatum-F. equiseti (FIESC) and F. chlamydosporum species complexes, also

${ }^{\dagger}$ Corresponding author: D. L. Funnell-Harris; E-mail: Deanna.Funnell-Harris@ars. usda.gov

Mention of trade names or commercial products in this article is solely for the purpose of providing specific information and does not imply recommendation or endorsement by the U.S. Department of Agriculture (USDA).

*The $\boldsymbol{e}$-Xtra logo stands for "electronic extra" and indicates that one supplementary table is published online.

This article is in the public domain and not copyrightable. It may be freely reprinted with customary crediting of the source. The American Phytopathological Society, 2017. have been isolated from sorghum grain (Funnell-Harris et al. 2010b, 2013b; Lincy et al. 2011; Sreenivasa et al. 2008). In addition to reduced grain quality, many of these species can produce mycotoxins that contaminate grain, which is of considerable concern for both humans and livestock (Bhat et al. 1997; Bowman and Hagler 1991; Shotwell et al. 1980).

Because airborne infection is the most likely source for grain mold, studies have been conducted that examine fungal spores sampled from air over or within sorghum fields. Using a semiselective medium to trap spores, Fusarium spp. isolates were collected from within sorghum fields, and both cultural and molecular techniques were used for identification (Funnell-Harris and Pedersen 2011). In general, spores found in sorghum field air samples were consistent with genera and species also identified from infected grain (Bandyopadhyay et al. 1991; Funnell-Harris and Pedersen 2011). Previous research also indicated that populations of Fusarium spp. are associated with grain mold diseases, as well as stalk, root, and crown diseases of grasses, rather than a single Fusarium sp. or pathovar (Funnell-Harris et al. 2010b; Parikka et al. 2012; Petrovic et al. 2013). It has also been shown that multiple Fusarium genotypes can be present in locally harvested maize kernels or wheat grains (Del Ponte et al. 2015; Morales-Rodríguez et al. 2007; Waalwijk et al. 2004). Fusarium spp. also may be found systemically from other infected plant parts to infect grain, as has been demonstrated in maize with the Fusarium ear rot pathogen, F. verticillioides (Munkvold and Carlton 1997; Murillo-Williams and Munkvold 2008). Plant genetic background and single gene differences may play a role in determining Fusarium spp. populations within plants (Funnell and Pedersen 2006; Funnell-Harris et al. 2010b; Gatch and Munkvold 2002).

Plants with brown midrib (bmr) mutations, which result in reduced lignin compared with wild-type counterparts, were previously shown to have differing Fusarium genotypes recovered from sorghum grain 
compared with near-isogenic wild-type lines (Funnell and Pedersen 2006; Funnell-Harris et al. 2010b; Oliver et al. 2005; Palmer et al. 2008). Sorghum is a model crop for $\mathrm{C}_{4}$ grasses (Pedersen et al. 2008) and, therefore, was the ideal species in which to incorporate two $\mathrm{bmr}$ mutant loci, bmr6 and bmr12, into six elite grain sorghum genetic backgrounds (Pedersen et al. 2006). It was subsequently demonstrated that biomass from the resulting mutant lines had increased feed efficiency in livestock (Oliver et al. 2005) and increased conversion efficiency into ethanol (Dien et al. 2009). The wild-type Bmr6 and Bmrl2 genes encode a cinnamyl alcohol dehydrogenase and a caffeic acid $O$-methyltransferase, which are enzymes in the monolignol biosynthesis pathway (Bout and Vermerris 2003; Saballos et al. 2009; Sattler et al. 2009, 2012). In general, reduced colonization of grain from bmr6 and bmrl2 lines by Fusarium spp.

TABLE 1. Mean monthly temperatures, precipitation, and irrigation at fields at Havelock in Lincoln, NE and at Mead, NE during sorghum growing months (May through October) during 2002, 2003, 2005, and 2006 ${ }^{\mathrm{a}}$

\begin{tabular}{|c|c|c|c|c|c|}
\hline Location & Year & Month & $\begin{array}{c}\text { Mean } \\
\text { temperature } \\
\left({ }^{\circ} \mathrm{C}\right)\end{array}$ & $\begin{array}{l}\text { Precipitation } \\
\quad(\mathrm{mm})\end{array}$ & $\begin{array}{l}\text { Irrigation } \\
(\mathrm{mm})^{\mathrm{b}}\end{array}$ \\
\hline \multirow[t]{6}{*}{ Lincoln } & \multirow[t]{6}{*}{2002} & May & 15.6 & 121 & 0 \\
\hline & & June & 25.5 & 2 & 0 \\
\hline & & July & 27.3 & 14 & 0 \\
\hline & & August & 24.4 & 213 & 0 \\
\hline & & September & 20.1 & 39 & 0 \\
\hline & & October & 8.5 & 107 & 0 \\
\hline \multirow[t]{6}{*}{ Mead } & \multirow[t]{6}{*}{2002} & May & 15.4 & 65 & 0 \\
\hline & & June & 25.0 & 20 & 50 \\
\hline & & July & 26.6 & 31 & 50 \\
\hline & & August & 23.4 & 137 & 50 \\
\hline & & September & 19.5 & 36 & 0 \\
\hline & & October & 7.9 & 63 & 0 \\
\hline \multirow[t]{6}{*}{ Lincoln } & \multirow[t]{6}{*}{2003} & May & 15.6 & 69 & 0 \\
\hline & & June & 20.5 & 169 & 0 \\
\hline & & July & 26.0 & 26 & 0 \\
\hline & & August & 25.1 & 33 & 0 \\
\hline & & September & 17.0 & 97 & 0 \\
\hline & & October & 13.1 & 25 & 0 \\
\hline \multirow[t]{6}{*}{ Mead } & \multirow[t]{6}{*}{2003} & May & 15.1 & 97 & 0 \\
\hline & & June & 20.4 & 66 & 0 \\
\hline & & July & 25.3 & 22 & 25 \\
\hline & & August & 24.2 & 29 & 150 \\
\hline & & September & 16.2 & 53 & 0 \\
\hline & & October & 12.0 & 39 & 0 \\
\hline \multirow[t]{6}{*}{ Lincoln } & \multirow[t]{6}{*}{2005} & May & 17.0 & 84 & 0 \\
\hline & & June & 23.9 & 109 & 0 \\
\hline & & July & 25.9 & 135 & 0 \\
\hline & & August & 23.3 & 41 & 0 \\
\hline & & September & 21.4 & 4 & 0 \\
\hline & & October & 12.3 & 58 & 0 \\
\hline \multirow[t]{6}{*}{ Mead } & \multirow[t]{6}{*}{2005} & May & 16.5 & 70 & 38 \\
\hline & & June & 23.8 & 22 & 38 \\
\hline & & July & 25.5 & 55 & 114 \\
\hline & & August & 22.9 & 20 & 76 \\
\hline & & September & 20.9 & 12 & 0 \\
\hline & & October & 12.1 & 45 & 0 \\
\hline \multirow[t]{6}{*}{ Lincoln } & \multirow[t]{6}{*}{2006} & May & 18.0 & 43 & 0 \\
\hline & & June & 23.8 & 65 & 0 \\
\hline & & July & 26.6 & 65 & 0 \\
\hline & & August & 23.9 & 117 & 0 \\
\hline & & September & 16.1 & 109 & 0 \\
\hline & & October & 9.4 & 24 & 0 \\
\hline \multirow[t]{6}{*}{ Mead } & \multirow[t]{6}{*}{2006} & May & 17.7 & 13 & 13 \\
\hline & & June & 23.2 & 20 & 38 \\
\hline & & July & 25.5 & 39 & 38 \\
\hline & & August & 22.9 & 120 & 76 \\
\hline & & September & 16.1 & 114 & 0 \\
\hline & & October & 9.4 & 19 & 0 \\
\hline
\end{tabular}

a Based on data from the High Plains Regional Climate Center, University of Nebraska, Lincoln (https://hprcc.unl.edu/awdn.php).

b Supplemental irrigation was applied at Mead using overhead irrigation, as needed. Sorghum was grown under dryland conditions at the Havelock field in Lincoln. was observed when compared with grain from wild-type lines (Funnell and Pedersen 2006; Funnell-Harris et al. 2010b). Furthermore, Fusarium proliferatum (Matsush.) Nirenberg ex Gerlach \& Nirenberg was significantly reduced in $b m r l 2$ grain, and an FIESC genotype was not detected in bmr 12 grain; however, both $F$. proliferatum and the FIESC genotype were common in both wild-type and bmr6 grain (Funnell-Harris et al. 2010b).

In previous studies, the $5^{\prime}$ portion of the translation elongation factor 1- $\alpha(T E F)$ gene was used to confirm morphological identification (Geiser et al. 2004) of individual Fusarium isolates from air samples and from $b m r$ and wild-type grain, and to conduct phylogenetic analysis of FIESC members from this grain (FunnellHarris and Pedersen 2011; Funnell-Harris et al. 2010b). The purpose of the present study was to test the following two hypotheses: (i) air samples from two sorghum field locations in eastern Nebraska have significantly different Fusarium populations and (ii) sorghum bmr and wild-type genotypes (both grain and leaves) are colonized by different Fusarium spp. and operational taxonomic units (OTU). The two locations were approximately $37.1 \mathrm{~km}$ apart and differed in that one field was irrigated (Mead) and the other was dryland (Havelock). The fungal isolates collected from grain and leaves from six wildtype sorghum cultivars and bmr6 and bmrl2 near-isogenic lines (Funnell and Pedersen 2006; Funnell-Harris et al. 2010b) and an expanded collection of isolates from air samples (Funnell-Harris and Pedersen 2011) were compared by sequence analysis at three phylogenetically informative loci: most of the internal transcribed spacer (ITS) region along with the $5^{\prime}$-variable region of the large subunit of nuclear ribosomal DNA (28S), and portions of the histone-3 (H3) and TEF genes (Geiser et al. 2004; Glass and Donaldson 1995; O'Donnell and Cigelnik 1997). Phylogenetic analyses of OTU, defined herein as the taxon at a unique tip within the phylogenetic tree, were performed using maximum-likelihood analysis, whereas the level of population differentiation, based on sequence polymorphism, was determined using Wright's $F$ statistic $\left(F_{S T}\right)$ and $K$ statistic $\left(K_{S T}\right)$. DNA polymorphisms and phylogenies were analyzed for members of the $F$. fujikuroi species complex and for all other Fusarium spp., including those in the F. graminearum species complex (FGSC) and FIESC.

\section{MATERIALS AND METHODS}

Collection of Fusarium isolates. Near-isogenic sorghum lines bmr6 and bmr12 in the genetic backgrounds BTх623, BTx630, BTx631, RTx430, 'Redlan', and 'Wheatland' were developed and, along with the wild-type lines, maintained by United States Department of Agriculture-Agricultural Research Service, Lincoln, NE (Pedersen et al. 2006). All 18 lines were grown during 2002 and 2003 at Lincoln and Mead, NE (Funnell and Pedersen 2006; FunnellHarris et al. 2010b) in four replicate plots per location and year. Eastern Nebraska has a humid continental climate with wet springs, warm to hot and humid summers and mild to cold and relatively dry autumns. Temperatures, precipitation and irrigation (Table 1), were recorded by the High Plains Regional Climate Center, University of Nebraska (UNL) (https://hprcc.unl.edu/awdn.php). Overhead sprinkler irrigation was applied to fields at Mead, NE, while Havelock fields in Lincoln lacked additional water applications. Observations have shown that when Fusarium isolates are collected from grain grown at both locations in the same year, more isolates are obtained from Mead than from Havelock, likely due to the application of overhead irrigation during anthesis and grain development (Table 1) (Funnell and Pedersen 2006; Funnell-Harris et al. 2010b, 2013b). A sample of approximately 20 mature grains (2002 to 2003) was collected from each of 10 randomly chosen plants (out of approximately 240 plants) per plot and the third leaf below the flag leaf (2002) was collected from each of five randomly chosen plants per plot, as previously described (Funnell and Pedersen 2006; FunnellHarris et al. 2010b). To isolate Fusarium spp., grains from the 10 plants from one plot were mixed, a subsample of 15 to 20 grains was 
surface disinfested, and 5 grains were aseptically placed onto each of two semiselective media: dichloran chloramphenicol peptone agar (DCPA) and pentachloronitrobenzene peptone agar (PCNB) (Funnell and Pedersen 2006; Funnell-Harris et al. 2010b). To isolate Fusarium spp. from leaf tissue, leaf disks $\left(\right.$ area $=1 \mathrm{~cm}^{2}$ ) were cut, surface disinfested, and aseptically placed onto DCPA medium at three leaf disks per each of five leaves from a plot and five disks per plate (Funnell and Pedersen 2006). All fungal colonies growing from each tissue onto the medium were transferred to half-strength potato dextrose agar (PDA; made with potato dextrose broth; BectonDickinson and Co., Sparks, MD). Further details of collection of Fusarium isolates from leaf tissues and grain are described by Funnell and Pedersen (2006) and Funnell-Harris et al. (2010b). For identification to species using morphological characteristics, presumptive Fusarium isolates were transferred to $1.5 \%$ water agar amended with $80 \mathrm{mM}$ potassium chloride $(\mathrm{KCl})$. Fusarium isolates were identified to species using colony, conidia, and conidiophore morphologies (Nelson et al. 1983), with identifications later confirmed by descriptions from Leslie and Summerell (2006), in addition to DNA sequences as described below. However, some Fusarium isolates with conidia, conidiophore, and colony characteristics did not fit well with a single species description; these were designated as Fusarium spp.

Fungi from air samples were collected by passive spore trapping onto PCNB at the Havelock field in Lincoln, NE and at Mead, NE during 2005 and 2006, by exposing the medium in Petri dishes, as previous reported by Funnell-Harris and Pedersen (2011), Briefly, Petri dishes with PCNB were placed at three heights, two within and one above the canopy, throughout sorghum fields, four times during the growing season on rain- and irrigation-free days (Funnell-Harris and Pedersen 2011): during vegetative growth (designated as 1), at anthesis (2), during grain development (3), and at grain maturity (harvest) (4). The study also examined exposure of the medium to air for different predetermined times, from $5 \mathrm{~min}$ to $24 \mathrm{~h}$. Numbers of fungi and Fusarium spp. colonies per square centimeter of agar medium per hour were previously analyzed and reported (FunnellHarris and Pedersen 2011). Temperature, precipitation, and irrigation data from 2005 and 2006 also are shown in Table 1. Colonies randomly chosen from each exposed plate were transferred to PDA, then $\mathrm{KCl}$, and identified to species as described above.

If multiple isolates of the same species were collected from the same plot (grain or leaf) or air-sampling plate, a representative isolate was chosen for further analysis. Representative grain, leaf, or air Fusarium isolates were single-conidium purified in the following way. Conidia from a $\mathrm{KCl}$ plate were gently dislodged using sterile purified water; then, a conidial suspension was streaked onto a peptone glucose agar plate ( $1 \%$ glucose, $0.5 \%$ peptone, $7 \mathrm{mM}$ potassium phosphate monobasic, $2 \mathrm{mM}$ magnesium sulfate heptahydrate, and $2.2 \%$ agar) amended with ampicillin (Sigma-Aldrich, St. Louis) at $100 \mu \mathrm{g} \mathrm{ml}^{-1}$. The plate was incubated at room temperature for 24 to $28 \mathrm{~h}$. Conidia were examined at $\times 25$ power using a stereoscopic zoom microscope with a high-resolution objective (Nikon Instruments, Inc., Melville, NY) and an individual germinating conidium was transferred to the center of a PDA plate ( 60 by $15 \mathrm{~mm}$ ) by cutting the agar around the germling using a flame-sterilized scalpel; in total, three germlings were transferred per isolate. Cultures were incubated at room temperature for 10 to 14 days, at which time the singleconidium-purified cultures were compared with the original isolate for morphological characteristics and a single isolate was chosen for each original culture. The single-conidium-purified isolates were stored (Funnell-Harris et al. 2013a) for further analyses. Amplification, sequencing, and comparison of sequences in FUSARIUM-ID was conducted on DNA from single-conidiumpurified isolates as described below to confirm morphological identification and to update to the most current name (Geiser et al. 2013)

DNA isolation, PCR amplification, and sequencing. Sequencing of $T E F, H 3$, and ITS was performed on DNA from 315 isolates: 186 obtained from air (74 from Mead and 112 from
Havelock in Lincoln), 93 from grain (62 from grain grown at Mead and 31 from Havelock), and 36 from leaf samples ( 8 from plants grown at Mead and 28 from Havelock). DNA was extracted from ground lyophilized mycelium from each isolate (Lee and Taylor 1990). For amplification of the $5^{\prime}$ region of the TEF gene, primer ef1 (forward primer: 5'-ATGGGTAAGGA(A/G)GACAAG AC-3') and ef 2 (reverse primer: 5'-GGA(G/A)GTACCAGT(G/C) ATCATGTT-3') and reaction mixture and conditions as previously published were used (Geiser et al. 2004). The entire ITS region along with the $5^{\prime}$ end of the $28 \mathrm{~S}$ ribosomal RNA also was amplified using primers ITS5 (forward: 5'-GGAAGTAAAAGTCGTAA CAAGG-3') and NL4 (reverse: GGTCCGTGTTTCAAGACGG), and the reaction mixture and conditions as previously published (O'Donnell 1996; O'Donnell and Cigelnik 1997; White et al. 1990). Amplification of $H 3$ was conducted using primers $\mathrm{H} 3-1 \mathrm{a}$ (forward: 5'ACTAAGCAGACCGCCCGCAGG-3') and H3-1b (reverse: 5' GCGGGCGAGCTGGATGTCCTT- $3^{\prime}$ ) and the reaction mixture previously described (Glass and Donaldson 1995), with the following conditions: $94^{\circ} \mathrm{C}$ for $5 \mathrm{~min}$; then 35 cycles of $92^{\circ} \mathrm{C}$ denaturation for $1 \mathrm{~min}, 56.5^{\circ} \mathrm{C}$ annealing for $1 \mathrm{~min}$, and $72^{\circ} \mathrm{C}$ extension for $1 \mathrm{~min}$; with a final extension at $72^{\circ} \mathrm{C}$ for $5 \mathrm{~min}$. Amplification products were either gel purified or column purified using the E.Z.N.A. Ultra-Sep Gel Extraction kit (Omega Bio-tek, Norcross, GA) or Amicon Ultra-015 Centrifugal Filter Device (Millipore, Billerica, MA), respectively. Purified amplification products were sequenced using the same primers as for amplification. Sequences from opposite strands were assembled using Sequencher 4.10.1 (Gene Codes, Corp., Ann Arbor, MI) and consensus TEF sequences were compared with those in the FUSARIUM-ID database (http://isolate.fusariumdb.org/guide.php) (Geiser et al. 2004) and GenBank for consensus sequences for all three regions for identification.

Because of their prevalence in grains (Bandyopadhyay et al. 2007; Funnell-Harris et al. 2010b; Leslie et al. 2005), Fusarium isolates classified as members of the $F$. fujikuroi species complex were analyzed separately from all other Fusarium spp. Fusarium isolates were segregated into $F$. fujikuroi species complex according to their TEF sequence identification, based on pairwise sequence alignments with isolates curated in FUSARIUM-ID (Leslie and Summerell 2006; Leslie et al. 2005; Nelson et al. 1983; O'Donnell et al. 1998). The regions of TEF and $H 3$ genes and ITS targeted for sequencing, alignment, and phylogenetic analysis for $F$. fujikuroi species complex and for other Fusarium spp. in this study were based on published sequences for $F$. verticillioides (Sacc.) Nirenberg 1976 and F. graminearum, respectively. For ITS, sequences were aligned to positions 5 through 1,046 based on accession GQ168841 (Wicklow and Poling 2009) for the F. fujikuroi species complex and bases 97 through 1,113 of accession FJ240316 (O'Donnell et al. 2008) for other Fusarium spp. For H3, sequences were aligned to positions 2 through 475 based on accession number AY435467 (Saleh and Leslie 2004) for the F. fujikuroi species complex and positions 24 through 472 based on accession GQ915473 (Proctor et al. 2009) for other Fusarium spp. For TEF, sequences were aligned to positions 28 through 684 based on accession JX269007 (FunnellHarris et al. 2013b) for the F. fujikuroi species complex isolates and positions 33 through 639 based on accession JF270252 for other Fusarium spp. (Funnell-Harris and Pedersen 2011). Representative sequences for each unique OTU were deposited into GenBank as accession numbers KX681483 to KX681488, KX681490 to KX681496, KX681498 to KX681534, KX681536 to KX681542, KX681544 to KX681575, KX681577 to KX681583, and KX681585 to KX681615. Accession numbers for sequences for each isolate as well as percent identities to sequences from representative isolates in FUSARIUM-ID (TEF) and BLAST searches in GenBank (ITS and $H 3$ ) are detailed in Supplementary Table S1. Species or species complex identifications relied primarily on morphological characteristics and comparisons of $T E F$ sequences and then, as needed, comparisons of ITS or $\mathrm{H} 3$ sequences. Sequences from representative 
isolates among those highly similar to sequences from isolates in this study are listed in the table.

Analyses of DNA polymorphisms in $T E F, H 3$, and ITS sequences. $T E F, H 3$, and ITS consensus sequences obtained from isolates collected from air, grain, and leaves were aligned and trimmed using the MUSCLE aligner (Edgar 2004) implemented in MEGA 5 (Tamura et al. 2011). The individual alignments from each locus were imported into jMODELTEST (version 2.1.10) (Darriba et al. 2012) to select best-fit models of nucleotide substitution optimized for maximum-likelihood tree topology using Akaike Information Criteria. For ITS, TIM + I + G was selected as the bestfit model whereas TPM2uf + G and TIM2 + I were selected for $T E F$ and $H 3$, respectively. The alignments for the three loci were concatenated together using the catfasta2phyml script available at https://github.com/nylander/catfasta2phyml. Before phylogenetic analysis, redundant sequences likely derived from identical isolates were removed from the alignment using CD-HIT (Li and Godzik 2006), with a global sequence similarity cutoff of $99.5 \%$ to account for potential errors in sequencing or assembly. A representative sequence was chosen for inclusion into the phylogenetic analysis and the number of isolates with sequences highly similar $(99.5 \%)$ to the representative sequence were enumerated. Maximum-likelihood trees were computed using GARLI (Zwicki 2006). Each locus was treated as a separate partition and allowed to evolve independently according to its optimal model of nucleotide substitution determined by jModelTest (ITS: TIM + I + G, TEF: TPM2uf + G, and H3: TIM2 + I). Evolution was simulated for 500,000 generations or until likelihood scores reached convergence, and nonparametric bootstrap analysis was performed to generate support for branching patterns ( $n=500$ pseudoreplicates). Bootstrap consensus trees were compiled using the sumtrees function of the Dendropy package (Sukumaran and Holder 2010). In total, three different phylogenetic trees were computed. For the F. fujikuroi species complex, a single phylogenetic tree including all three loci was produced. However, $H 3$ did not amplify well for certain Fusarium spp. other than those in the F. fujikuroi species complex (for example, F. sporotrichioides, $F$. graminearum, and some members of the FIESC); therefore, two phylogenetic trees were constructed for this fungal group. The first tree included all three loci while the second tree included only ITS and $T E F$, so that taxa missing sequences for $H 3$ could be included in the phylogenetic comparisons.

$F_{S T}$ and $K_{S T}$ scores, along with $P$ values for $K_{S T}$ scores, were computed using the program DNASP (version 5) (Librado and Rozas 2009) using the Gene Flow and Population Differentiation Analysis. Sites with alignment gaps were considered as a fifth state and a permutation test was run on all possible pairwise treatment comparisons to generate statistical support for predicted population differentiation. For interpretation of level of differentiation as indicated by $F_{S T}$ scores, the following scale was used: $F_{S T} \leq 0.15$ as low differentiation, $0.25 \geq F_{S T}>0.15$ as moderate differentiation, and $F_{S T}>0.25$ as strong differentiation (Karubian et al. 2015; Lowe and Allendorf 2010; Ottewell et al. 2016). For $K_{S T}$ scores, significance was indicated at $P \leq 0.05$.

\section{RESULTS}

Maximum-likelihood analyses of $\boldsymbol{F}$. fujikuroi species complex sequences from sorghum field isolates. OTU is defined herein as the taxon at a unique tip within the phylogenetic tree (Daly et al. 2001; McCaig et al. 1999). Multiple OTU were identified for each species: F. proliferatum, F. thapsinum Klittich, J. F. Leslie, P. E. Nelson \& Marasas (synonym G. thapsina Klittich, J. F. Leslie, P. E. Nelson \& Marasas), F. subglutinans (Wollenw. \& Reinking) P. E. Nelson, Toussoun \& Marasas 1983, and F. verticillioides (Fig. 1). $F$. proliferatum, $F$. thapsinum, $F$. subglutinans, and $F$. verticillioides each had the presence of sequences assigned on multiple tips within

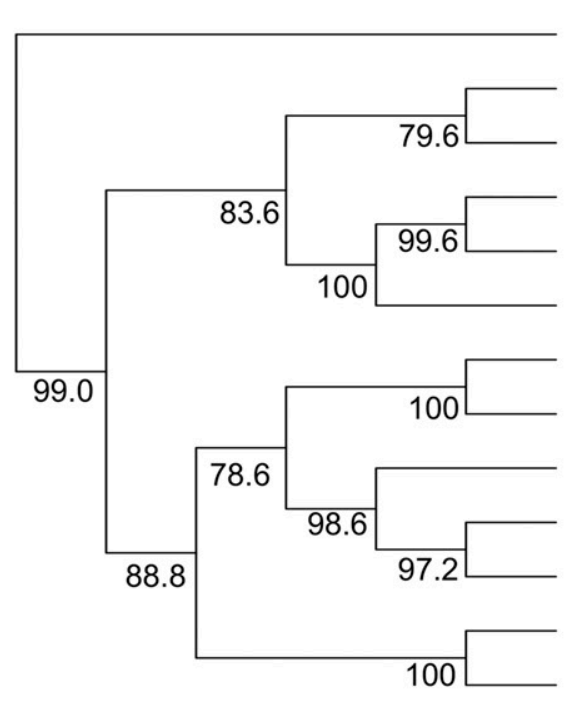

Fusarium sp.

Fusarium sp. Fusarium sp.

F. proliferatum

F. proliferatum

F. proliferatum

F. thapsinum

F. thapsinum

F. verticillioides

F. verticillioides

F. verticillioides

F. subglutinans

F. subglutinans

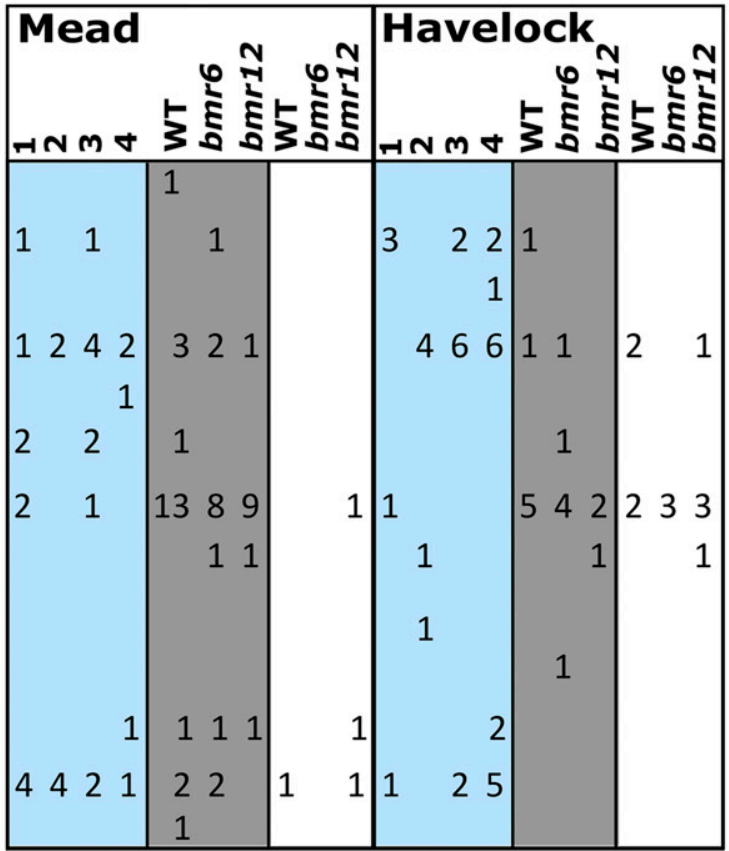

Air Seed Leaf Air Seed Leaf

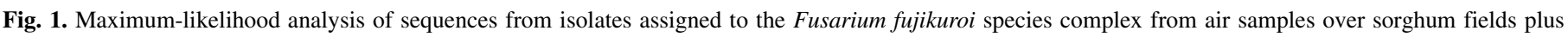

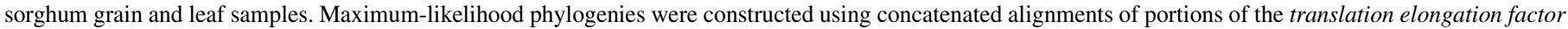

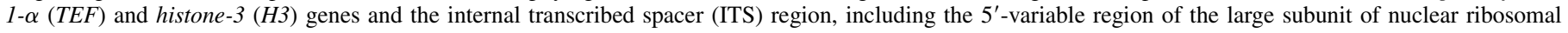

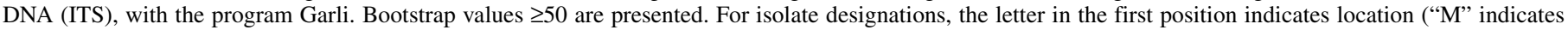

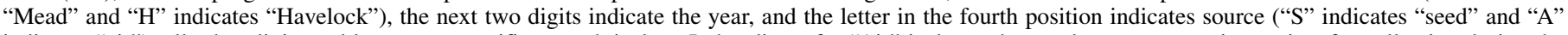

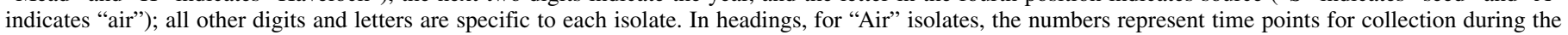

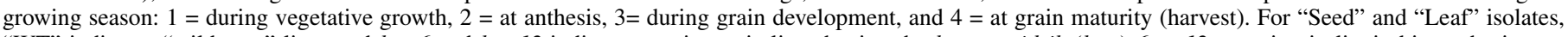
"WT" indicates "wild-type" lines and bmr6 and bmr12 indicate near-isogenic lines having the brown midrib (bmr)-6 or 12 mutation in lignin biosynthesis. 
the phylogenetic tree. One OTU within each species occurred more frequently among all the air and plant (grain and leaf) samples than the others. For example, the $F$. proliferatum OTU represented by the grain isolate M03S_A2_91 was common in air samples from both locations, nearly throughout the growing seasons, and was commonly isolated from leaves from Havelock and grain from both locations. Most other $F$. proliferatum OTU were detected at a much lower frequency and in one or only a few environments (Fig. 1). The exception was one of two Fusarium sp. OTU, represented by isolate H03S_C1_2, which grouped in the same clade as most $F$. proliferatum OTU and was detected in grain and air samples from both Mead and Havelock. This isolate, and isolates H06A_4K_1b and M02S_C1_5, had characteristics that placed them into the $F$. fujikuroi species complex but could not be definitively identified to species. There were only two F. thapsinum OTU identified using the three concatenated loci (Fig. 1). The OTU represented by isolate H03S_A1_2 was frequently recovered from plant tissues at Mead in grain and at Havelock in grain and leaves collected at harvest in 2002 and 2003. However, it was detected only at low levels from air samples during the 2005 and 2006 growing seasons. The other $F$. thapsinum OTU, represented by isolate M02S_A1_92, was detected in grain only at low levels and only detected in air samples once at Havelock. There also were only two $F$. subglutinans OTU identified (Fig. 1). The predominant OTU, represented by isolate M02S_A1_92, was isolated at most air sampling time points at both locations; however, this OTU was isolated from plant tissues (grain and leaves) only at Mead. Although there were three $F$. verticillioides OTU identified, this species was detected at relatively low levels in the environments screened during this study (Fig. 1). The most common OTU, represented by isolate M03S_C1_5a, was detected in air samples at harvest at both locations and in plant tissues (grain and leaves) at Mead.

In summary, four species and three Fusarium sp. OTU from within the $F$. fujikuroi species complex were found in association with sorghum and air samples over sorghum fields. Only F. proliferatum, F. thapsinum, and one of the Fusarium sp. OTU (represented by isolate H03S_C1_2) were present in plants and air at both locations. For $F$. proliferatum and $F$. thapsinum, only a single OTU each (M03S_A2_91 and H03S_A1_2, respectively) was present in air and plant samples at both Mead and Havelock.

Maximum-likelihood analyses of sequences from other Fusarium spp. and species complexes in plant and air samples from sorghum fields. Among the numerous OTU identified after concatenation of ITS, TEF, and $H 3$ sequences, the most frequent were members of the FGSC and the FIESC (Fig. 2A). This study detected nine $F$. graminearum OTU but the most commonly detected in most samples, and the only one detected in plant tissues, was the OTU represented by isolate M02S_C2_3. For FIESC, 10 OTU were detected, representing eight different genotypes (O'Donnell et al. 2009), with 3 OTU for genotype FIESC 25-a,b,c, the only FIESC genotype with multiple OTU (Fig. 2A). Most of the FIESC genotypes were rarely detected in sorghum plant tissues or only detected in air samples. FIESC 18-a,b was detected in air samples at both locations during 2005 and 2006 and detected in grain grown at Mead during 2002 and 2003. The most commonly detected OTU of FIESC 25-a,b,c, represented by the leaf isolate H02L_C3_11a, was only found at Havelock but was detected in air, grain, and leaf samples (Fig. 2A). Although at low levels, FIESC 24-a was present in air and plant samples (grain at Mead and both grain and leaf tissue at Havelock) at both locations.

Because there were difficulties amplifying the $H 3$ gene in a few genotypes of FIESC and in F. graminearum and F. sporotrichioides, a reanalysis conducted by concatenating ITS and TEF sequences was done (Fig. 2B). When sequences with more than $99.5 \%$ sequence identity were collapsed, fewer representative OTU resulted than when all three sequences were used in analysis. Among the four FGSC OTU, isolate M02S_C2_3 still represented the most common OTU in air samples at both locations (Fig. 2B). This isolate was placed in the same clade as two F. armeniacum (G. A. Forbes,
Windels \& L. W. Burgess) L. W. Burgess \& Summerell OTU and a Fusarium sp. The Fusarium sp. OTU, represented by isolate H05A_1D_4, was present at low levels in air samples and plants (leaf tissue at Mead and both grain and leaf tissue at Havelock) at both locations (Fig. 2B). This analysis resulted in OTU for nine FIESC genotypes, with one FIESC 4-b air isolate in the same clade as FIESC 1-a, 4-b isolates (Fig. 2B). There were only two OTU for FIESC 25-a, $\mathrm{b}, \mathrm{c}$ in this analysis, including the one represented by the leaf isolate H02L_C3_11a, which was predominately found in plants (grain and leaves) sampled at Havelock but was also detected in grain from Mead.

$F_{S T}$ and $K_{S T}$ analyses of $\boldsymbol{F u s a r i u m}$ sequences from bmr6, bmr12, and wild-type plants. $F_{S T}$ analysis, which indicates the degree of genetic differentiation between populations, was performed on all Fusarium isolates cultured from wild-type, bmr6, and bmr12 grain (Havelock, NE and Mead, NE) and leaves (Havelock only) (Table 2) by comparing sequences from TEF, ITS, and $H 3$ sequences. $F_{S T}$, a value between 0 (identical) and 1 (entirely differentiated), indicated that populations in wild-type and bmr6 grain grown at Havelock were highly similar. However, the $F_{S T}$ values from Mead were much higher, indicating that the populations of Fusarium isolates from wild-type, bmr6, and bmrl2 grain grown at Mead were more different from one another than those from wildtype and bmr6 grain grown at Havelock (Table 2). These results indicated that sorghum genotypes and location (environment) effected Fusarium OTU in the grain. Although adequate numbers of leaf isolates were collected from wild-type and bmr6 plants only from the Havelock field, there were indications that these populations also were strongly differentiated (Table 2); environmental influences could not be indicated for leaf populations.

$K_{S T}$ was also conducted to provide further insights into the $F_{S T}$ results. Because $K_{S T}$ values were generated on two groups, the F. fujikuroi species complex and all other Fusarium spp. (Figs. 1 and 2 , respectively), they indicated what fungal groups may have contributed to observed differentiation between the populations (Table 3). Comparing TEF, H3, and ITS sequences (the same sequences used for $F_{S T}$ analysis) between populations in wild-type and $b m r$ grain grown at Mead provided evidence that Fusarium spp. OTU not within the F. fujikuroi species complex (other Fusarium spp.) may have contributed to observed differences in these populations indicated by $F_{S T}$ analysis (Tables 2 and 3; Fig. 2A). However, $K_{S T}$ values do not support significant differences in grain and leaf OTU populations at $P<0.05$ (Tables 2 and 3; Figs. 1 and 2).

$F_{S T}$ and $K_{S T}$ analyses of Fusarium sequences from air samples at sorghum fields. Fusarium populations from air samples at Havelock and Mead over two growing seasons were compared using concatenated sequences from $T E F, H 3$, and ITS from all Fusarium isolates. $F_{S T}$ values for all pairwise comparisons between each time point at Havelock were very close to zero or had low differentiation, which indicated that the populations were highly similar (Table 4). For Fusarium populations in air samples, comparisons between time points 2 (anthesis) and 4 (grain maturity) indicated similar levels of low differentiation at both locations, while other comparisons between time points at each location indicated that those populations were essentially the same (close to zero) (Table 4). The populations at the same time point taken at different locations also were compared (Table 4). In this case, populations taken at time point 2 (during anthesis) were strongly differentiated whereas $F_{S T}$ at time point 1 (vegetative growth) and the two later time points ( 3 and $4=$ grain development and maturity, respectively) were nearly 0 , suggesting a high degree of similarity.

$K_{S T}$ analysis supported population differentiation between time point 1 and the three later time points sampled at Havelock among the F. fujikuroi species complex OTU but not all other Fusarium spp., which was not apparent when using $F_{S T}$ assessment alone (Tables 3 and 4). $K_{S T}$ analysis also indicated that differences between populations at the two locations were due to differences among $F$. fujikuroi species complex isolates and all other Fusarium spp. 


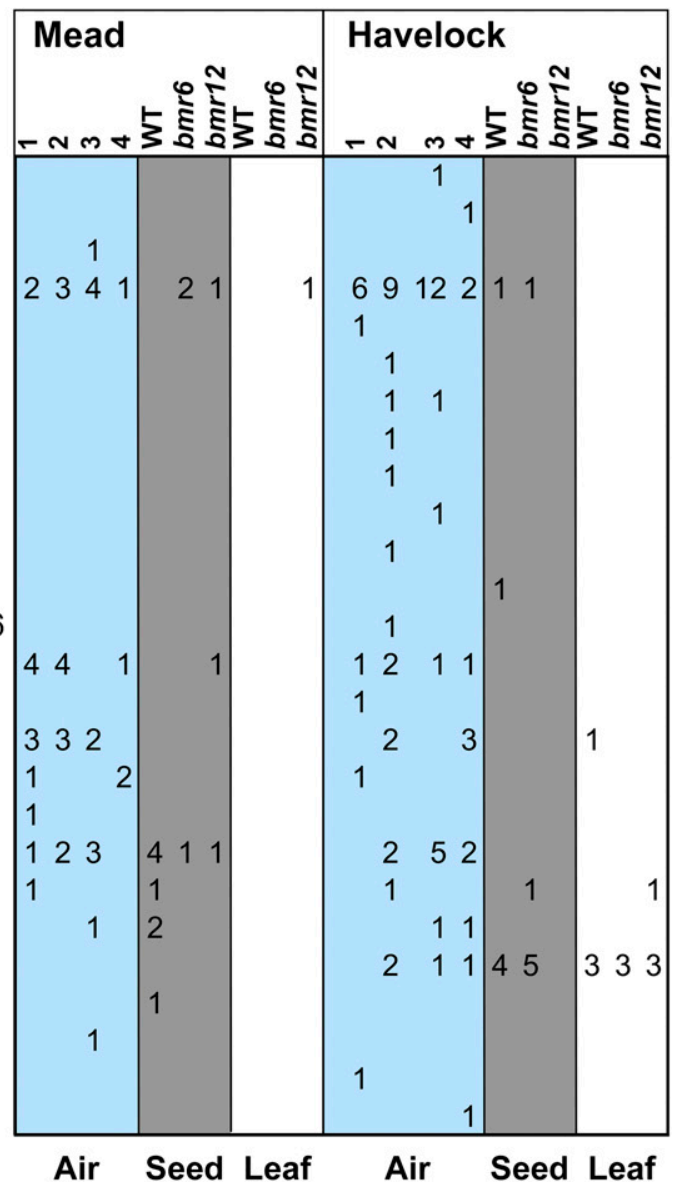

\section{B}

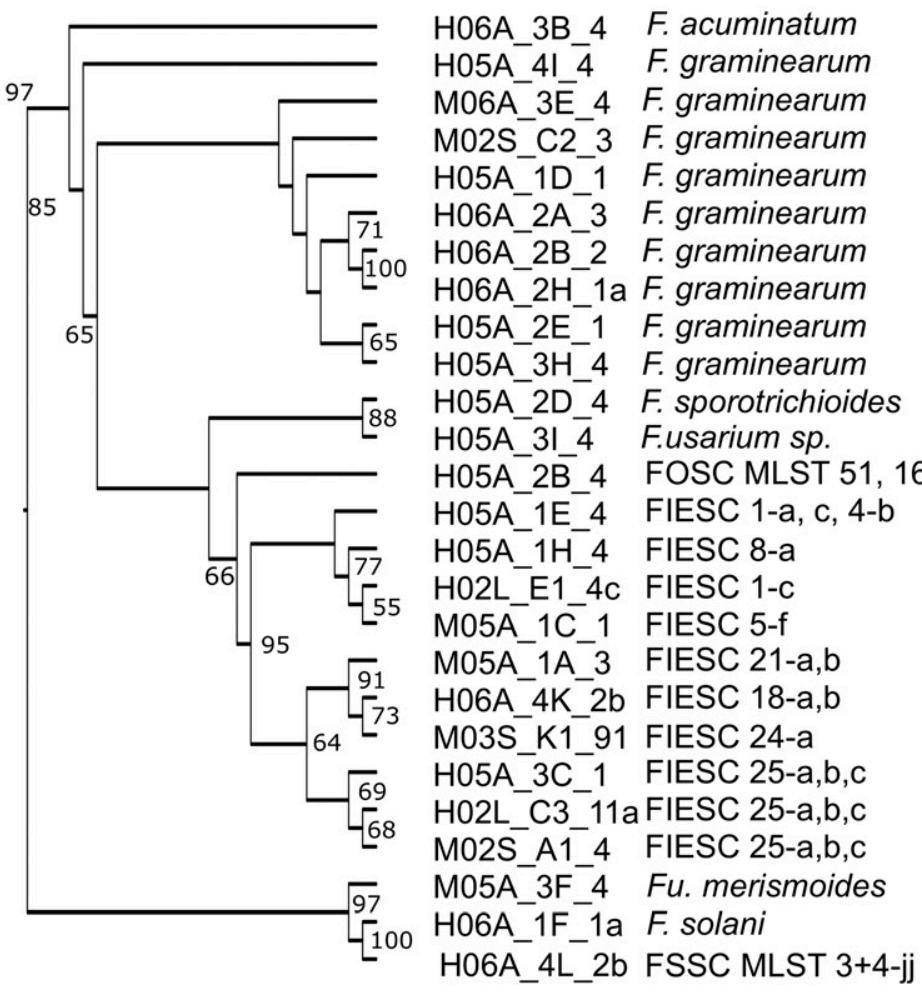

H06A_3B_4 F. acuminatum

F. graminearum

M02S_C2 3 F. graminearum

H05A $1 \mathrm{D}^{-1}$ F. graminearum

H06A $2 \mathrm{~A} 3$ F. graminearum

H06A_2B_2 F. graminearum

H06A_2H_1a F. graminearum

H05A 2E 1 F. graminearum

H05A $3 \mathrm{H}_{4}$ F. graminearum

H05A_2D_4 F. sporotrichioides

H05A 314 Fusarium sp.

H05A $2 \bar{B} 4$ FOSC MLST 51, 161, 216

H05A 1E 4 FIESC 1-a, c, 4-b

H05A_1H_4 FIESC 8-a

H02L E1 4c FIESC 1-C

M05A 1C 1 FIESC 5-f

M05A_1A_3 FIESC 21-a,b

H06A 4K 2b FIESC 18-a,b

M03S K1 91 FIESC 24-a

M02S A1 4 FIESC 25-a,b,c

H06A_1F_1a F. solani

H06A_4L_2b FSSC MLST 3+4-jj

Air Seed Leaf Air Seed Leaf

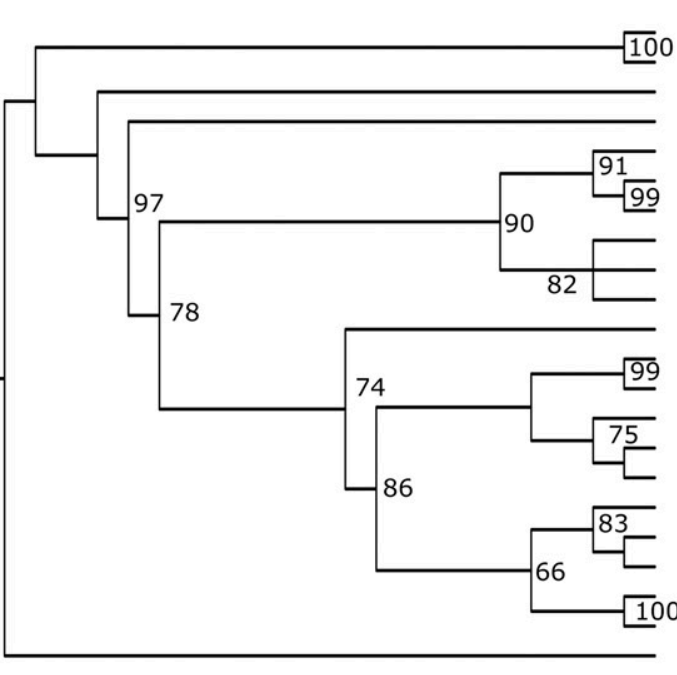

H06A_1F_1a F. solani

H06A 4L $2 b$ FSSC MSLT 3+4-jj

H06A_3B_4 F. acuminatum

H05A 4I 4 F. graminearum

M02L A2 2a F. armeniacum

H02L_K3_5b F. armeniacum

H05A 1D_4 Fusarium sp.

$\mathrm{H}^{06 \mathrm{~A}} 4 \mathrm{~K}-3 \mathrm{~d}$ F. graminearum

M02S_C2_3 F. graminearum

M06A-3E-4 F. graminearum

H05A_2B_4 FOSC MSLT 51, 161, 216

H05A $1 \mathrm{E}^{-} 4$ FIESC 1-a,4-b

M06A 2K 1 FIESC 4-b

$\mathrm{H} 02 \mathrm{~L}$ E1_4C FIESC 1-C

$\mathrm{H}_{05 \mathrm{~A}} 1 \mathrm{H}^{-} 4$ FIESC 8-a

M05A $1 C^{-1}$ FIESC 5-f

M05A-1A-3 FIESC 21-a,b

H06A 2E-2 FIESC 18-a,b

M03S_K1_91 FIESC 24-a

H02L_C3_11aFIESC 25-a,b,c

H05A 3C 1 FIESC 25-a,b,c

M05A_3F_4 Fu. merismoides

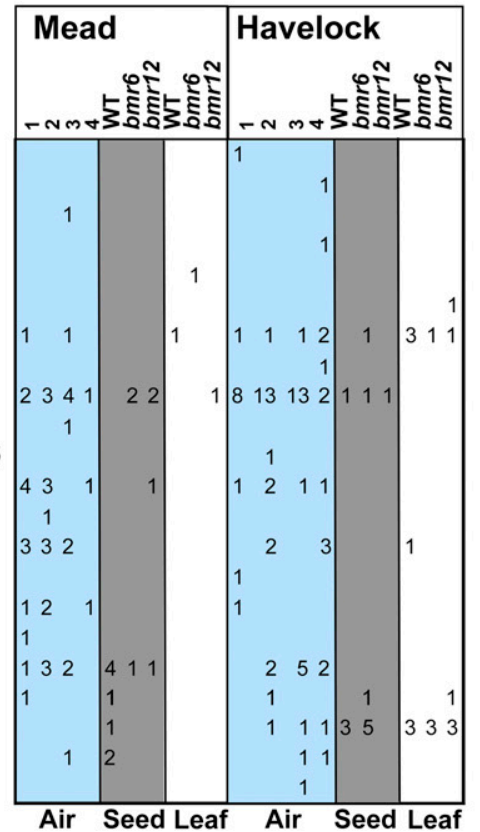

Fig. 2. Maximum-likelihood analysis of sequences from isolates classified as Fusarium spp. other than those in the Fusarium fujikuroi species complex from air samples over sorghum fields plus sorghum grain and leaf samples. Samples were taken from two locations: Mead, NE and Havelock field in Lincoln, NE. Maximum-likelihood phylogenies were constructed using concatenated alignments of portions of the A, translation elongation factor 1- $\alpha$ (TEF) and histone-3 (H3) genes and the internal transcribed spacer (ITS) region, including the $5^{\prime}$ variable region of the large subunit of nuclear ribosomal DNA, and B, TEF and ITS only. The program Garli was used to construct phylogenies. Bootstrap values $\geq 50$ are presented. "F." indicates "Fusarium", "FOSC" indicates "Fusarium oxysporum species complex", "MLST" indicates "multilocus sequence typing", "FIESC" indicates "F. incarnatum-F. equiseti species complex", "Fu." indicates "Fusicolla", and "FSSC" indicates "F. solani species complex". For isolate designations, the letter in the first position indicates location ("M" indicates "Mead" and " $\mathrm{H}$ " indicates "Havelock"), the next two digits indicate the year, and the letter in the fourth position indicates source ("S" indicates "seed", "L" indicates "leaf", and "A" indicates "air"). In headings, for "Air" isolates, the numbers represent time points for collection during the growing season: $1=$ during vegetative growth, 2 = at anthesis, 3 = during grain development, and 4 = at grain maturity (harvest). For "Seed" and "Leaf" isolates, "WT" indicates "wild-type" lines and bmr6 and bmr12 indicate near-isogenic lines having the brown midrib (bmr)-6 or 12 mutation in lignin biosynthesis. 


\section{DISCUSSION}

The first hypothesis tested was that air samples from two sorghum field locations in Nebraska have significantly different Fusarium populations. Although this appears to be a straightforward hypothesis, it was not supported throughout the growing season. Results from $F_{S T}$ and $K_{S T}$ showed that, during anthesis of the sorghum crop growing season (time point 2), populations of aerial propagules of Fusarium spp. were strongly differentiated (Tables 3 and 4) but, early in the growing season (vegetative growth) and at later time points during the season (grain development and harvest), there was less differentiation between the populations at the two locations. The time periods from flowering through physiological maturity are when grain infections are likely to occur (Menkir et al. 1996; Navi et al. 2005). Thus, it is expected that grain pathogens would be prevalent in air samples during these time periods (Bandyopadhyay et al. 1991); however, in the current study, the greatest differences in infections between the two locations would occur if conditions were conducive to infection at anthesis (Navi et al. 2005). Less is known about leaf infections of sorghum and other grasses (Larran et al. 2007; Murillo-Williams and Munkvold 2008; Wagacha et al. 2012). Presumably, Fusarium spp. could infect leaves by way of aerial spores, spores dispersed from infected debris by rain or irrigation splash, or through systemic infections of panicles or roots (Bateman et al. 2007; FunnellHarris and Pedersen 2011; Funnell-Harris et al. 2010a; MurilloWilliams and Munkvold 2008).

The second hypothesis tested was that sorghum $\mathrm{bmr}$ and wildtype genotypes are colonized by different Fusarium spp. and OTU. A previous study indicated that grain of near-isogenic bmr lines had unique differences in Fusarium spp. compared with the wild type for both members of the $F$. fujikuroi species complex and all other Fusarium spp. (Funnell-Harris et al. 2010b). $F_{S T}$ analysis of population differentiation when considering TEF, H3, and ITS sequence comparisons among all isolates collected supported this previous observation and showed population differentiation at the

TABLE 2. Genetic similarity between populations, as indicated by Wright's $F$ statistic $\left(F_{S T}\right)$, of Fusarium grain and leaf isolates from three sorghum genotypes grown at two locations (Havelock field in Lincoln, NE and Mead, NE), and between grain and leaf isolates of the same plant genotype grown at Havelock, that could be attributed to differences in the concatenated sequences of portions of the translation elongation factor and histone-3 genes and the internal transcribed spacer region ${ }^{\mathrm{a}}$

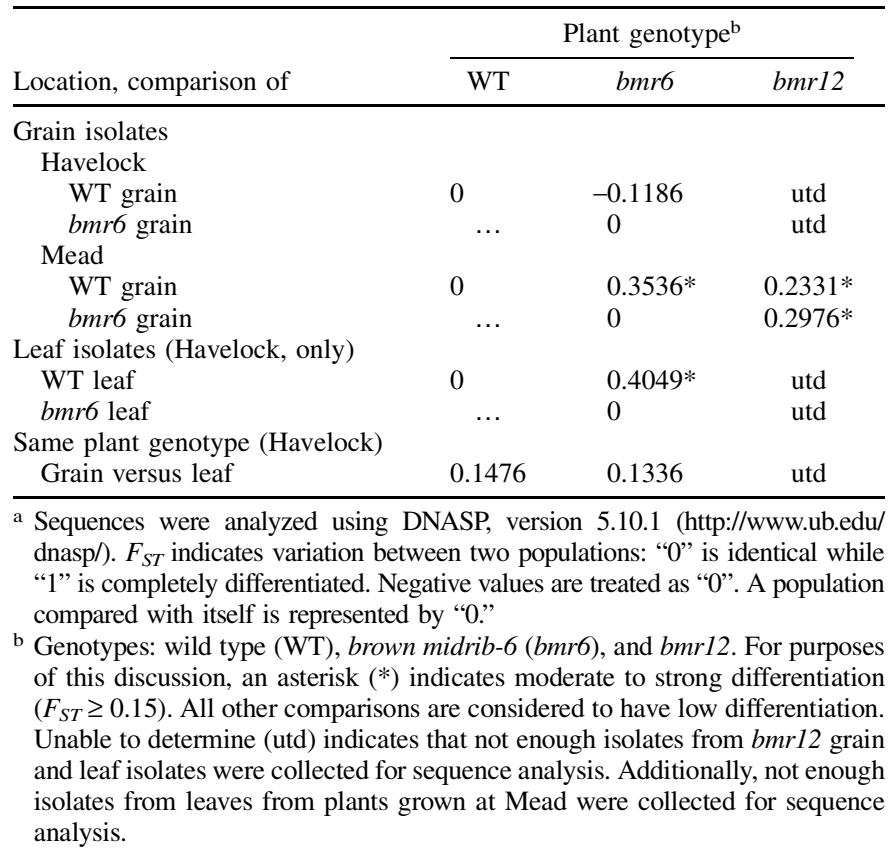

OTU level (Table 2). The populations were subdivided into the F. fujikuroi species complex and all other Fusarium spp. for $K_{S T}$ analysis, which suggested that this differentiation was due to differences in all other Fusarium spp. rather than to differences in

TABLE 3. $K$ statistics $\left(K_{S T}\right)$ and $P$ values for Fusarium population comparisons of isolates collected at Mead, NE and at the Havelock field in Lincoln, $\mathrm{NE}^{\mathrm{a}}$

\begin{tabular}{|c|c|c|c|c|c|c|}
\hline \multirow{2}{*}{$\begin{array}{l}\text { Isolates, location, } \\
\text { comparison }^{\mathrm{c}}\end{array}$} & \multicolumn{2}{|c|}{$\begin{array}{c}\text { FFSC-TEF- } \\
H 3-\text { ITS }^{\mathrm{b}}\end{array}$} & \multicolumn{2}{|c|}{$\begin{array}{l}\text { OF-TEF-H3- } \\
\text { ITS }\end{array}$} & \multicolumn{2}{|c|}{ OF-TEF-ITS } \\
\hline & $K_{S T}$ & $P$ & $K_{S T}$ & $P$ & $K_{S T}$ & $P$ \\
\hline \multicolumn{7}{|l|}{ Plant isolates } \\
\hline \multicolumn{7}{|l|}{ Mead } \\
\hline WT \& bmr6 grain & -0.0123 & 0.82 & 0.0880 & 0.07 & -0.0978 & 0.89 \\
\hline WT \& bmr 12 grain & 0.0068 & 0.27 & 0.0774 & 0.08 & -0.0286 & 0.73 \\
\hline $\begin{array}{l}\text { bmr6 \& bmr12 } \\
\text { grain }\end{array}$ & 0.0113 & 0.21 & -0.0950 & 0.70 & -0.1400 & 0.90 \\
\hline \multicolumn{7}{|l|}{ Havelock } \\
\hline WT \& bmr6 grain & -0.0212 & 0.58 & -0.0399 & 0.82 & -0.0389 & 0.88 \\
\hline WT \& bmr 12 grain & -0.1744 & 0.81 & na & na & na & na \\
\hline $\begin{array}{l}\text { bmr6 \& bmr12 } \\
\text { grain }\end{array}$ & -0.1891 & 0.86 & na & na & na & na \\
\hline WT \& bmr6 leaf & -0.2287 & 0.97 & -0.1290 & 1.00 & -0.0978 & 0.90 \\
\hline WT \& bmr12 leaf & -0.1748 & 0.91 & -0.0324 & 0.74 & -0.0286 & 0.73 \\
\hline$b m r 6 \& b m r 12$ leaf & na & na & -0.0611 & 0.67 & -0.1400 & 0.89 \\
\hline WT grain \& leaf & -0.0038 & 0.39 & -0.0180 & 0.54 & 0.0316 & 0.2 \\
\hline bmr6 grain \& leaf & -0.2234 & 0.98 & -0.0832 & 0.97 & -0.1370 & 0.98 \\
\hline bmr12 grain \& leaf & -0.2630 & 0.87 & na & na & na & na \\
\hline \multicolumn{7}{|c|}{ Air isolates } \\
\hline \multicolumn{7}{|l|}{ Mead } \\
\hline TP $1 \& 2$ & 0.0068 & 0.33 & -0.0207 & 0.76 & -0.0190 & 0.93 \\
\hline TP $1 \& 3$ & -0.0221 & 0.68 & 0.0223 & 0.13 & 0.0173 & 0.13 \\
\hline TP $1 \& 4$ & 0.0047 & 0.32 & -0.0059 & 0.53 & -0.0104 & 0.64 \\
\hline TP $2 \& 3$ & 0.0481 & 0.13 & 0.0032 & 0.32 & 0.0053 & 0.30 \\
\hline TP $2 \& 4$ & 0.0605 & 0.16 & 0.0014 & 0.44 & -0.0083 & 0.56 \\
\hline TP $3 \& 4$ & -0.0282 & 0.82 & 0.0032 & 0.38 & 0.0006 & 0.43 \\
\hline \multicolumn{7}{|l|}{ Havelock } \\
\hline TP $1 \& 2$ & 0.0399 & 0.05 & 0.0018 & 0.28 & -0.0043 & 0.49 \\
\hline TP $1 \& 3$ & 0.0125 & 0.08 & 0.0035 & 0.30 & -0.0018 & 0.40 \\
\hline TP $1 \& 4$ & 0.0059 & 0.15 & 0.0559 & 0.02 & 0.0464 & 0.02 \\
\hline TP $2 \& 3$ & -0.0040 & 0.76 & -0.0059 & 0.70 & -0.0090 & 0.82 \\
\hline TP $2 \& 4$ & 0.0451 & 0.18 & 0.0090 & 0.16 & 0.0247 & 0.03 \\
\hline TP $3 \& 4$ & 0.0135 & 0.67 & 0.0216 & 0.05 & 0.0321 & 0.03 \\
\hline \multicolumn{7}{|l|}{ Mead \& Havelock } \\
\hline TP 1 & -0.0181 & 0.62 & 0.0972 & $<0.01$ & 0.0925 & $<0.01$ \\
\hline ТР 2 & 0.2077 & 0.05 & 0.0204 & 0.07 & 0.0393 & 0.02 \\
\hline TP 3 & -0.0406 & 0.84 & -0.0070 & 0.58 & 0.0037 & 0.29 \\
\hline TP 4 & -0.0250 & 0.86 & -0.0106 & 0.76 & -0.0085 & 0.59 \\
\hline
\end{tabular}

a Operational taxonomic units (OTU) were determined by sequence analysis of portions of the translation elongation factor 1- $\alpha$ (TEF) and histone-3 (H3) genes and the internal transcribed spacer (ITS) region that includes the $5^{\prime}$ variable region of the $28 \mathrm{~S}$ ribosomal RNA. Samples were taken from brown midrib (bmr)-6, bmr12, and wild-type (WT) grain (Havelock and Mead) and leaves (Havelock) and air over sorghum fields (Havelock and Mead). Time points (TP) for air samples were $1=$ during vegetative growth, $2=$ at anthesis, $3=$ during grain development, and $4=$ at grain maturity (harvest). Fusarium isolates were divided into two groups for analysis: those in the Fusarium fujikuroi species complex (FFSC) and all other Fusarium (OF) species. Comparisons are based on results of Wright's $F$ statistic and $K_{S T}$ analyses for detecting genetic differentiation between two populations. When $P \leq 0.05$, the two populations are considered significantly differentiated (values in bold). Not applicable (na) indicates that not enough isolates from bmr12 grain and leaf isolates were collected at Havelock for sequence analysis. Additionally, not enough isolates from leaves from plants grown at Mead were collected for sequence analysis.

b $F$. fujikuroi species complex (FFSP) OTU were analyzed using the concatenated sequences of $T E F, H 3$, and ITS. OF haplotypes were analyzed using the concatenated sequences of TEF, $H 3$, and ITS, and TEF and ITS, to account for DNA from a few other Fusarium spp. that did not consistently amplify using the $H 3$ primers.

${ }^{c}$ Comparisons (separated by an ampersand) are between populations in plant samples (grain or leaf) from two plant genotypes grown at the same location, between two air sample TP at the same location, or air samples from two locations conducted at the same TP. 
members of the F. fujikuroi species complex (Table 3). However, both analyses showed that such differences were apparent at Mead, $\mathrm{NE}$ but not at the Havelock field in Lincoln, indicating that environment could determine whether differences in Fusarium populations between $b m r$ and wild-type lines were observed (Tables 2,3 , and 4). The bmr6 and bmr12 lines in this study had mutations that impair lignin biosynthesis (Bout and Vermerris 2003; Palmer et al. 2008; Saballos et al. 2009; Sattler et al. 2009, 2012). Previous studies had shown that each mutation affects lignin content, composition, and levels of other phenolic intermediates but that genetic background also had an effect on these traits (Oliver et al. 2005; Palmer et al. 2008). Another study provided evidence that sorghum genotype affected the microorganisms associated with the rhizosphere (Funnell-Harris et al. 2010a). In the current study, analyses across six genetic backgrounds suggested that both bmr6 and $b m r 12$ loci had a moderate to strong effect on grain- and leafinfecting Fusarium OTU at the Mead location but much less effect at Havelock.

$F_{S T}$ and $K_{S T}$ are indicators of the proportion of variability between populations that could be attributed to sequence differences (Hudson et al. 1992a,b). $K_{S T}$ provides a statistical measurement that operates maximally when populations within a sample number approximately 50. Although, in the current study, population numbers were relatively low, differentiation in air populations between the two locations was indicated at earlier time points. $K_{S T}$ analyses also supported differentiation of populations between the two locations for time point 2 (Tables 3 and 4). Combining $F_{S T}$ and $K_{S T}$ analyses suggested that differences between the air populations at the two locations may have been due to other Fusarium spp. at time point 1 and both the $F$. fujikuroi species complex and other Fusarium spp. at time point 2. For example, at time points 1 and 2, there were several $F$. graminearum isolates represented by OTU

TABLE 4. Genetic similarity between populations, as indicated by Wright's F-statistic $\left(F_{S T}\right)$, of Fusarium air isolates collected at sorghum fields in Lincoln, NE (Havelock field) and Mead, NE, during vegetative growth (time point 1 ), anthesis (time point 2 ), grain development (time point 3 ), and grain maturity (4) over 2 years $^{\mathrm{a}}$

\begin{tabular}{lc}
\hline Location, comparison & $F_{S T}$ \\
\hline Population, different times ${ }^{\mathrm{b}}$ & \\
Havelock & 0.0709 \\
1 versus 2 & 0.0242 \\
1 versus 3 & 0.0156 \\
1 versus 4 & -0.0078 \\
2 versus 3 & 0.1077 \\
2 versus 4 & 0.0281 \\
3 versus 4 & -0.0587 \\
Mead & 0.0509 \\
1 versus 2 & -0.1210 \\
1 versus 3 & 0.0248 \\
1 versus 4 & 0.1017 \\
2 versus 3 & -0.0720 \\
2 versus 4 & -0.0395 \\
3 versus 4 & $0.3264 *$ \\
Two locations, same timec & -0.07945 \\
1 & -0.1113 \\
2 & \\
3 &
\end{tabular}

M02S_C2_3 at Havelock and fewer at Mead (Fig. 2) whereas, at time point 2, F. subglutinans OTU M02S_A1_92 was more apparent at Mead than at Havelock (Fig. 1). Therefore, combining $F_{S T}$ and $K_{S T}$ analyses was informative on population differentiation within Fusarium groups in different environments.

OTU is commonly used in microbial ecology to describe groups of individuals that share sequence similarity above a certain threshold, usually at $97 \%$ nucleotide sequence similarity or higher (Daly et al. 2001; Fierer et al. 2007; McCaig et al. 1999). This approach was used in the current study to group fungal isolates with at least $99.5 \%$ sequence similarity in order to determine how the abundance of each group of fungi changed over time (air samples) or how fungi were present in leaves and grain collected from different sorghum genotypes. For the phylogenetic analysis presented, a representative sequence from each OTU (generally the most abundant sequence within the OTU) was used to construct the tree. Although multiple OTU were assigned to the same fungal species complexes in several cases, it is beyond the scope of the work to determine whether these OTU represent new variants, strains, or haplotypes within these species complexes.

Among the members of the F. fujikuroi species complex, there were multiple OTU detected for each species, or Fusarium isolates not yet identified to species that grouped in the same clade as OTU with specific epithets, for air, grain, and leaf isolates. However, there was just one dominant OTU found in plant tissues for each species (Fig. 1). The $F$. subglutinans OTU represented by isolate M02S_A1_92, was detected in air samples taken at both locations (2005 and 2006) but only in plant tissues (grain and leaves) grown at Mead (2002 and 2003). These data suggested that environmental conditions at irrigated Mead fields were more conducive for infection by this OTU than conditions at the dryland Havelock field. One F. thapsinum OTU, represented by isolate H03S_A1_2, was most prevalent in grain and leaf samples; however, both OTU were found in grain and leaf samples but detected in air samples only at low levels. In another study conducted at Mead and Havelock during 2005, F. thapsinum was detected in grain from both locations, indicating that infection of sorghum grain by this species was common despite low detection levels in air (FunnellHarris et al. 2013b); however, further analyses will need to be conducted to determine whether the same OTU were present in both air and plant tissues during that year.

Several OTU were identified among the other Fusarium spp. but most were only detected from air samples. When using the concatenated $T E F, H 3$, and ITS sequences, the most commonly detected OTU from air samples was $F$. graminearum, represented by isolate M02S_C2_3, which constituted 54\% of the colonies sampled for sequencing (Fig. 2A). The closely related species also found in North America, F. pseudograminearum O'Donnell \& T. Aoki 1999 (Aoki and O'Donnell 1999; Smiley et al. 2016), was not isolated in this study. One of three OTU of FIESC genotype 25-a,b,c (represented by isolate H02L_C3_11a) was only detected in air, grain, and leaf samples from the Havelock field in Lincoln, NE. Another FIESC OTU, genotype 18-a,b represented by isolate M02S_A1_4, was detected in air samples from both Mead and Havelock but only detected in grain grown at Mead. These last two cases provided evidence that environmental conditions may affect sporulation or sorghum infection by different members of FIESC (Bottalico and Perrone 2002; Dorn et al. 2011).

Inconsistent amplification of the $H 3$ gene fragment from isolates of a few species occurred. Although most (93.0\%) of the Fusarium isolates analyzed in the present study had an amplified $H 3$ fragment, DNA from a few FIESC, F. graminearum, and F. sporotrichioides genotypes did not consistently yield amplification products. Therefore, ITS and TEF sequences were concatenated and the analysis was repeated. Results for FIESC genotypes were similar between the two analyses. However, three $F$. graminearum OTU, two $F$. armeniacum OTU, and one Fusarium sp. OTU were all grouped in the same clade. Little is known of F. armeniacum (Burgess and Summerell 2000; 
Burgess et al. 1993). It originally was considered a subspecies of F. acuminatum but was reassigned to its own species due to its greater toxigenicity (Wing et al. 1993) and electrophoretic karyotype differences (Nagy and Hornok 1994). F. armeniacum has been isolated from grain crops and grasses (Burgess et al. 1993; Funnell-Harris et al. 2010b; Kommedahl et al. 1979; Nagy and Hornok 1994) and, unlike F. graminearum, was shown to produce T-2 trichothecenes (Wing et al. 1993). Despite differences in mycotoxin production, the current study provides evidence of the phylogenetic relationships between these two species.

In summary, screening of air, grain, and leaf isolates from multiple environments indicated that, within a species group, one or two OTU were dominant across most environments tested. Exceptions included $F$. subglutinans and FIESC 18-a,b OTU that were present in air samples at both locations but only present in grain $(F$. subglutinans and FIESC 18-a,b) and leaves (F. subglutinans) taken at Mead; and the dominant FIESC 25-a,b,c OTU, which was present only in air and plant samples (grain and leaves) taken from Havelock. On the other hand, the $F$. thapsinum OTU that was dominant in grain samples from both locations, representing $62.1 \%$ of $F$. fujikuroi species complex grain isolates and $44.1 \%$ of total grain isolates, was detected only at low levels from air samples. A likely explanation is the dominance of maize production in this region of Nebraska (Healey et al. 2011), which could result in the presence of conidia primarily from maize pathogens such as $F$. proliferatum and $F$. graminearum (Jurjevic et al. 2005; Schmale and Bergstrom 2004). This could explain the greater number of OTU from these maize pathogens in air samples identified for each of these species in the present study (Figs. 1 and 2). Although additional investigations are required to determine the aerial patterns and pathogenicity of different $F$. thapsinum OTU, these results lend further support to the previously proposed idea that $F$. thapsinum may be particularly aggressive toward and perhaps specialized on sorghum (Leslie et al. 2004). The present study also provided evidence indicating that air populations at two locations in Nebraska were differentiated earlier in the growing season (e.g., during anthesis) but were much more similar later (during grain development), when infection by pathogens would likely occur (FunnellHarris and Pedersen 2008; Navi et al. 2005). This study presented evidence that fungal populations in grain and leaf samples from $b m r 6$, bmr12, and wild-type lines across six genetic backgrounds may be different, which suggested that changes to lignin biosynthesis, and the consequential changes to lignin content, its composition, or levels of other phenolic compounds, have a substantial effect on infection by Fusarium spp. It had been previously demonstrated that Fusarium pathogens could be inhibited during in vitro growth assays by phenolic compounds that were elevated in some bmr lines, which led to the hypothesis that free phenolics accumulating in $b m r$ plants acted as a resistance mechanism (Funnell-Harris et al. 2014). However, it was recently demonstrated that free phenolic extracts from bmr6 plants did not inhibit in vitro growth of $F$. thapsinum; thus, it was proposed that cell-wall-bound phenolics or inducible defense compounds, as a result of increased salicylic acid levels in $b m r$ plants, may reduce in planta growth of some fungal pathogens (FunnellHarris et al. 2010b, 2017).

\section{ACKNOWLEDGMENTS}

This research was supported by United States Department of Agriculture-Agricultural Research Service Current Research Information System project number 5440-21220-027-00D and National Institute of Food and Agriculture grant number 2011-67009-30026. We thank J. Toy for overseeing field operations, C. Nguyen and Z. Van Roy for technical assistance, and $\mathrm{H}$. Tetreault for valuable discussions.

\section{LITERATURE CITED}

Alves dos Reis, T., Zorzete, P., Rodrigues Pozzi, C., Nascimento da Silva, V., Ortega, E., and Correa, B. 2010. Mycoflora and fumonisin contamination in
Brazilian sorghum from sowing to harvest. J. Sci. Food Agric. 90: 1445-1451.

Aoki, T., and O'Donnell, K. 1999. Morphological and molecular characterization of Fusarium pseudograminearum sp. nov., formerly recognized as the group 1 population of $F$. graminearum. Mycologia 91:597-609.

Audilakshmi, S., Das, I. K., Ghorade, R. B., Mane, P. N., Kamatar, M. Y., Narayana, Y. D., and Seetharama, N. 2011. Genetic improvement of sorghum for grain mould resistance: I. Performance of sorghum recombinant inbred lines for grain mould reactions across environments. Crop Prot. 30: 753-758.

Bandyopadhyay, R., Kumar, M., and Leslie, J. F. 2007. Relative severity of aflatoxin contamination of cereal crops of West Africa. Food Addit. Contam. 24:1109-1114.

Bandyopadhyay, R., Muchocho, L. K., and Satyanarayana, M. V. 1991. Occurrence of airborne spores of fungi causing grain mould over a sorghum crop. Mycol. Res. 95:1315-1320.

Bateman, G. L., Gutteridge, R. J., Gherbawy, Y., Thomsett, M. A., and Nicholson, P. 2007. Infection of stem bases and grains of winter wheat by Fusarium culmorum and F. graminearum and effects of tillage method and maize-stalk residues. Plant Pathol. 56:604-615.

Bhat, R. V., Shetty, P. H., Amruth, R. P., and Sudershan, R. V. 1997. A foodborne disease outbreak due to the consumption of moldy sorghum and maize containing fumonisin mycotoxins. Clin. Toxicol. 35:249-255.

Bottalico, A., and Perrone, G. 2002. Toxigenic Fusarium species and mycotoxins associated with head blight in small grain cereals in Europe. Eur. J. Plant Pathol. 108:611-624.

Bout, S., and Vermerris, W. 2003. A candidate-gene approach to clone the sorghum Brown midrib gene encoding caffeic acid $O$-methyltransferase. Mol. Genet. Genomics 269:205-214.

Boutigny, A.-L., Beukes, I., Small, I., Zuhlke, S., Spiteller, M., Van Rensburg, B. J., Flett, B., and Viljoen, A. 2012. Quantitative detection of Fusarium pathogens and their mycotoxins in South African maize. Plant Pathol. 61: 522-531.

Bowman, D. T., and Hagler, J. W. M. 1991. Potential use of visual mold ratings to predict mycotoxin contamination of grain sorghum. J. Prod. Agric. 4: 132-134.

Burgess, L. W., Forbes, G. A., Windels, C. E., Nelson, P. E., Marasas, W. F. O., and Gott, K. P. 1993. Characterization and distribution of Fusarium acuminatum subsp. armeniacum subsp. nov. Mycologia 85:119-124.

Burgess, L. W., and Summerell, B. A. 2000. Taxonomy of Fusarium: Fusarium armeniacum Stat \& comb. nov. Mycotaxon 75:347-348.

Castor, L. L., and Frederiksen, R. A. 1982. Grain deterioration in sorghum. Pages 163-169 in: Proc. Int. Symp. Sorghum Grain Quality. L. W. Rooney, D. S. Murty, and J. V. Mertin, eds. ICRISAT Center, Patencheru, India.

Daly, K., Stewart, C. S., Flint, H. J., and Shirazi-Beechey, S. P. 2001. Bacterial diversity within the equine large intestine as revealed by molecular analysis of cloned 16S rRNA genes. FEMS Microbiol. Ecol. 38:141-151.

Darriba, D., Taboada, G. L., Doallo, R., and Posada, D. 2012. jModelTest 2: More models, new heuristics and parallel computing. Nat. Methods 9:772.

Del Ponte, E. M., Spolti, P., Ward, T. J., Gomes, L. B., Nicolli, C. P., Kuhnem, P. R., Silva, C. N., and Tessmann, D. J. 2015. Regional and field-specific factors affect the composition of Fusarium head blight pathogens in subtropical no-till wheat agroecosystem of Brazil. Phytopathology 105: 246-254.

Denis, J. C., and Girard, J. C. 1980. Factors affecting the development of sorghum grain molds in Senegal. Pages 144-153 in: Proc. Int. Workshop Sorghum Dis. R. J. Williams, R. A. Frederiksen, and L. K. Mughogho, eds. ICRISAT, Andhra Pradesh, India.

Dien, B. S., Sarath, G., Pedersen, J. F., Sattler, S. E., Chen, H., Funnell-Harris, D. L., Nichols, N. N., and Cotta, M. A. 2009. Improved sugar conversion and ethanol yield for forage sorghum (Sorghum bicolor L. Moench) lines with reduced lignin contents. Bioenerg. Res. 2:153-164.

Dorn, B., Forrer, H. R., Jenny, E., Wettstein, F. E., Bucheli, T. D., and Vogelgsang, S. 2011. Fusarium species complex and mycotoxins in grain maize from maize hybrid trials and from grower's fields. J. Appl. Microbiol. 111:693-706.

Edgar, R. C. 2004. MUSCLE: Multiple sequence alignment with high accuracy and high throughput. Nucleic Acids Res. 32:1792-1797.

Fierer, N., Breitbart, M., Nulton, J., Salamon, P., Lozupone, C., Jones, R., Robeson, M., Edwards, R. A., Felts, B., Rayhawk, S., Knight, R., Rohwer, F., and Jackson, R. B. 2007. Metagenomic and small-subunit rRNA analyses reveal the genetic diversity of bacteria, archaea, fungi and viruses in soil. Appl. Environ. Microbiol. 73:7059-7066.

Funnell, D. L., and Pedersen, J. F. 2006. Reaction of sorghum lines genetically modified for reduced lignin content to infection by Fusarium and Alternaria spp. Plant Dis. 90:331-338.

Funnell-Harris, D. L., O’Neill, P. M., Sattler, S. E., Gries, T., Berhow, M. A., and Pedersen, J. F. 2017. Response of sorghum stalk pathogens to brown 
midrib plants and soluble phenolic extracts from near isogenic lines. Eur. J. Plant Pathol. 148:941-953.

Funnell-Harris, D. L., and Pedersen, J. F. 2008. Inoculation strategies to assess biological interactions between Fusarium and Alternaria species infecting sorghum. Can. J. Plant Pathol. 30:404-413.

Funnell-Harris, D. L., and Pedersen, J. F. 2011. Presence of Fusarium spp. in air and soil associated with sorghum fields. Plant Dis. 95:648-656.

Funnell-Harris, D. L., Pedersen, J. F., and Sattler, S. E. 2010a. Soil and root populations of fluorescent Pseudomonas spp. associated with seedlings and field-grown plants are affected by sorghum genotype. Plant Soil 335: 439-455.

Funnell-Harris, D. L., Pedersen, J. F., and Sattler, S. E. 2010b. Alteration in lignin biosynthesis restricts growth of Fusarium spp. in brown midrib sorghum. Phytopathology 100:671-681.

Funnell-Harris, D. L., Prom, L. K., and Pedersen, J. F. 2013a. Isolation and characterization of the grain mold fungi Cochliobolus and Alternaria spp. from sorghum using semiselective media and DNA sequence analyses. Can. J. Microbiol. 59:87-96.

Funnell-Harris, D. L., Prom, L. K., Sattler, S. E., and Pedersen, J. F. 2013b. Response of near-isogenic sorghum lines, differing at the $P$ loculs for plant colour, to grain mould and head smut fungi. Ann. Appl. Biol. 163:91-101.

Funnell-Harris, D. L., Sattler, S. E., and Pedersen, J. F. 2014. Response of Fusarium thapsinum to sorghum brown midrib lines and to phenolic metabolites. Plant Dis. 98:1300-1308.

Gatch, E. W., and Munkvold, G. P. 2002. Fungal species composition in maize stalks in relation to European corn borer injury and transgenic insect protection. Plant Dis. 86:1156-1162.

Geiser, D. M., Aoki, T., Bacon, C. W., Baker, S. E., Bhattacharyya, M. K., Brandt, M. E., Brown, D. W., Burgess, L. W., Chulze, S., Coleman, J. J., Correll, J. C., Covert, S. F., Crous, P. W., Cuomo, C. A., De Hoog, G. S., Di Pietro, A., Elmer, W. H., Epstein, L., Frandsen, R. J. N., Freeman, S., Gagkaeva, T., Glenn, A. E., Gordon, T. R., Gregory, N. F., Hammond-Kosack, K. E., Hanson, L. E., del Mar Jimenez-Gasco, M., Kang, S., Kistler, H. C., Kuldua, G. A., Leslie, J. F., Logrieco, A., Lu, G., Lysoe, E., Ma, L.-J., McCormick, S. P., Migheli, Q., Moretti, A., Munaut, F., O’Donnell, K., Pfennig, L., Ploetz, R. C., Proctor, R. H., Rehner, S. A., Robert, V. A. R. G., Rooney, A. P., bin Salleh, B., Scandiani, M. M., Scauflaire, J., Short, D. P. G., Steenkamp, E., Suga, H., Summerell, B. A., Sutton, D. A., Thrane, U., Trail, F., Van Diepeningen, A., VanEtten, H. D., Viljoen, A., Waalwijk, C., Ward, T. J., Wingfield, M. J., Xu, J.-R., Yang, X.-B., Yli-Mattila, T., and Zhang, N. 2013. One fungus, one name: Defining the genus Fusarium in a scientifically robust way that preserves longstanding use. Phytopathology 103:400-408.

Geiser, D. M., del Mar Jimenez-Gasco, M., Kang, S., Makalowska, I., Veeraraghavan, N., Ward, T. J., Zhang, N., Kuldua, G. A., and O'Donnell, K. 2004. FUSARIUM-id v. 1.0: A DNA sequence database for identifying Fusarium. Eur. J. Plant Pathol. 110:473-479.

Glass, N. L., and Donaldson, G. C. 1995. Development of primer sets designed for use with the PCR to amplify conserved genes from filamentous ascomycetes. Appl. Environ. Microbiol. 61:1323-1330.

Han, Z., Tangui, E. K., Huybrechts, B., Munaut, F., Scauflaire, J., Wu, A., and Callebaut, A. 2014. Screening survey of co-production of fusaric acid, fusarin $\mathrm{C}$, and fumonisins $\mathrm{B}_{1}, \mathrm{~B}_{2}$ and $\mathrm{B}_{3}$ by Fusarium strains grown in maize grains. Mycotoxin Res. 30:231-240.

Healey, N. C., Irmak, A., Hubbard, K. G., and Lenters, J. D. 2011. Environmental variables controlling site suitability for corn-based ethanol production in Nebraska. Biomass Bioenergy 35:2852-2860.

Hudson, R. R., Boos, D. D., and Kaplan, N. L. 1992a. A statistical test for detecting geographic subdivision. Mol. Biol. Evol. 9:138-151.

Hudson, R. R., Slatkin, M., and Maddison, W. P. 1992b. Estimation of levels of gene flow from DNA sequence data. Genetics 132:583-589.

Jurjevic, Z., Wilson, D. M., Wilson, J. P., Geiser, D. M., Juba, J. H., Mubatanhema, W., Widstrom, N. W., and Rains, G. C. 2005. Fusarium species of the Gibberella fujikuroi complex and fumonisin contamination of pearl millet and corn in Georgia, USA. Mycopathologia 159:401-406.

Karubian, J., Ottewell, K., Link, A., and Di Fiore, A. 2015. Genetic consequences of seed dispersal to sleeping trees by white-bellied spider monkeys. Acta Oecol. 68:50-58.

Kommedahl, T., Windels, C. E., and Stucker, R. E. 1979. Occurrence of Fusarium species in roots and stalks of symptomless corn plants during the growing season. Phytopathology 69:961-966.

Larran, S., Perello, A., Simon, M. R., and Moreno, V. 2007. The endophytic fungi from wheat (Triticum aestivum L.). World J. Microbiol. Biotechnol. 23:565-572.

Lee, S. B., and Taylor, J. W. 1990. Isolation of DNA from fungal mycelia and single spores. Pages 282-287 in: PCR Protocols: A Guide to Methods and Applications. M. A. Innis, D. H. Gelfand, J. J. Sninsky, and T. J. White, eds. Harcourt, Brace Jovanovich, Publishers, San Diego, CA.
Leslie, J. F., and Summerell, B. A., eds. 2006. The Fusarium Laboratory Manual. Blackwell Publishing, Ames, IA. doi:10.1002/9780470278376

Leslie, J. F., Zeller, K. A., Lamprecht, S. C., Rheeder, J. P., and Marasas, W. F. O. 2005. Toxicity, pathogenicity, and genetic differentiation of five species of Fusarium from sorghum and millet. Phytopathology 95:275-283.

Leslie, J. F., Zeller, K. A., Logrieco, A., Mule, G., Moretti, A., and Ritieni, A. 2004. Species diversity of and toxin production by Gibberella fujikuroi species complex strains isolated from native prairie grasses in Kansas. Appl. Environ. Microbiol. 70:2254-2262.

Li, W., and Godzik, A. 2006. Cd-hit: A fast program for clustering and comparing large sets of protein or nucleotide sequences. Bioinformatics 22: 1658-1659.

Librado, P., and Rozas, J. 2009. DnaSP v5: A software for comprehensive analysis of DNA polymorphism data. Bioinformatics 25:1451-1452.

Lincy, S. V., Chandrashekar, A., Narayan, M. S., Sharma, R., and Thakur, R. P. 2011. Natural occurrence of trichothecene-producing Fusaria isolated from India with particular reference to sorghum. World J. Microbiol. Biotechnol. 27:981-989.

Lowe, W. H., and Allendorf, F. W. 2010. What can genetics tell us about population connectivity? Mol. Ecol. 19:3038-3051.

McCaig, A. E., Glover, A., and Prosser, J. I. 1999. Molecular analysis of bacterial community structure and diversity in unimproved and improved upland grass pastures. Appl. Environ. Microbiol. 65:1721-1730.

Menkir, A., Ejeta, G., Butler, L. G., Melakeberhan, A., and Warren, H. L. 1996. Fungal invasion of kernels and grain mold damage assessment in diverse sorghum germplasm. Plant Dis. 80:1399-1402.

Morales-Rodríguez, I., Yanez-Moralez, M. J., Silva-Rojas, H. V., Garcia-de-los-Santos, G., and Guzman-de-Pena, D. A. 2007. Biodiversity of Fusarium species in Mexico associated with ear rot in maize, and their identification using a phylogenetic approach. Mycopathologia 163:31-39.

Munkvold, G. P., and Carlton, W. M. 1997. Influence of inoculation method on systemic Fusarium moniliforme infection of maize plants grown form infected seeds. Plant Dis. 81:211-216.

Murillo-Williams, A., and Munkvold, G. P. 2008. Systemic infection by Fusarium verticillioides in maize plants grown under three temperature regimes. Plant Dis. 92:1695-1700.

Nagy, R., and Hornok, L. 1994. Electrophoretic karyotype differences between two subspecies of Fusarium acuminatum. Mycologia 86:203-208.

Navi, S. S. 2006. Fungi associated with sorghum grains in rural Indian storages. J. New Seeds 7:51-68.

Navi, S. S., Bandyopadhyay, R., Reddy, R. K., Thakur, R. P., and Yang, X. B. 2005. Effects of wetness duration and grain development stages on sorghum grain mold infection. Plant Dis. 89:872-878.

Nelson, P. E., Toussoun, T. A., and Marasas, W. F. O. 1983. Fusarium Species: An Illustrated Manual for Identification. The Pennsylvania State University Press, University Park.

O'Donnell, K. 1996. Progress toward a phylogenetic classification of Fusarium. Sydowia 48:57-70.

O’Donnell, K., and Cigelnik, E. 1997. Two divergent intragenomic rDNA ITS2 types within a monophyletic lineage of the fungus Fusarium are nonorthologous. Mol. Phylogenet. Evol. 7:103-116.

O’Donnell, K., Cigelnik, E., and Nirenberg, H. I. 1998. Molecular systematics and phylogeography of the Gibberella fujikuroi species complex. Mycologia 90:465-493.

O'Donnell, K., Sutton, D. A., Rinaldi, M. G., Gueidan, C., Crous, P. W., and Geiser, D. M. 2009. Novel multilocus sequence typing scheme reveals high genetic diversity of human pathogenic members of the Fusarium incarnatum$F$. equiseti and F. chlamydosporum species complexes within the United States. J. Clin. Microbiol. 47:3851-3861.

O’Donnell, K., Ward, T. J., Aberra, D., Kistler, H. C., Aoki, T., Orwig, N., Kimura, M., Bjornstad, A., and Klemsdal, S. S. 2008. Multilocus genotyping and molecular phylogenetics resolve a novel head blight pathogen within the Fusarium graminearum species complex from Ethiopia. Fungal Genet. Biol. 45:1514-1522.

Oliver, A. L., Pedersen, J. F., Grant, R. J., Klopfenstein, T. J., and Jose, H. D. 2005. Comparative effects of the sorghum $b m r-6$ and $b m r-12$ genes: II. Grain yield, stover yield, and stover quality in grain sorghum. Crop Sci. 45: 2240-2245.

Ottewell, K. M., Bickerton, D. C., Byrne, M., and Lowe, A. J. 2016. Bridging the gap: A genetic assessment framework for population-level threatened plant conservation prioritization and decision-making. Divers. Distrib. 22: 174-188.

Palmer, N. A., Sattler, S. E., Saathoff, A. J., Funnell, D., Pedersen, J. F., and Sarath, G. 2008. Genetic background impacts soluble and cell wall-bound aromatics in brown midrib mutants of sorghum. Planta 229:115-127.

Parikka, P., Hakala, K., and Tiilikkala, K. 2012. Expected shifts in Fusarium composition on cereal grain in Northern Europe due to climate change. Food Addit. Contam. Part A Chem. Anal. Control Expo. Risk Assess. 29: 1543-1555. 
Pedersen, J. F., Funnell, D., Toy, J. J., Oliver, A. L., and Grant, R. J. 2006. Registration of twelve grain sorghum genetic stocks near-isogenic for the brown midrib genes bmr-6 and bmr-12. Crop Sci. 46:491-492.

Pedersen, J. F., Toy, J. J., Funnell, D., Sattler, S. E., Oliver, A. L., and Grant, R. J. 2008. Registration of BN611, AN612, BN612, and RN613 sorghum genetic stocks with staked $b m r-6$ and $b m r-12$. J. Plant Regist. 2:258-262.

Petrovic, T., Burgess, L. w., Cowie, I., Warren, R. A., and Harvey, P. R. 2013. Diversity and fertility of Fusarium sacchari from wild rice, (Oryza australiensis) in Northern Australia, and pathogenicity tests with wild rice, rice, sorghum and maize. Eur. J. Plant Pathol. 136:773-788.

Proctor, R. H., McCormick, S. P., Alexander, N. J., and Desjardin, A. E. 2009. Evidence that a secondary metabolic biosynthetic gene cluster has grown by gene relocation during evolution of the filamentous fungus Fusarium. Mol. Microbiol. 74:1128-1142.

Saballos, A., Ejeta, G., Sanchez, E., Kang, C. H., and Vermerris, W. 2009. A genomewide analysis of the cinnamyl alcohol dehydrogenase family in sorghum [Sorghum bicolor (L.) Moench] identifies SbCad2 as the brown midrib6 gene. Genetics 181:783-795.

Saleh, A. A., and Leslie, J. F. 2004. Cephalsporium maydis is a distinct species in the Gaeumannomyces-Harpophora species complex. Mycologia 96: 1294-1305.

Sattler, S. E., Palmer, N. A., Saballos, A., Greene, A. M., Xin, Z., Sarath, G., Vermerris, W., and Pedersen, J. F. 2012. Identification and characterization of four missense mutations in Brown midrib as (Bmr12), The caffeic $O$-methyltransferase (COMT) of sorghum. Bioenerg. Res. 5:855-865.

Sattler, S. E., Saathoff, A. J., Haas, E. J., Palmer, N. A., Funnell-Harris, D. L., Sarath, G., and Pedersen, J. F. 2009. A nonsense mutation in a cinnamyl alcohol dehydrogenase gene is responsible for the sorghum brown midrib6 phenotype. Plant Physiol. 150:584-595.

Schmale, D. G. I., and Bergstrom, G. C. 2004. Spore deposition of the ear rot pathogen, Gibberella zeae, inside corn canopies. Can. J. Plant Pathol. 26: 591-595.

Sharma, R., Thakur, R. P., Senthilvel, S., Rao, V. P., and Varshney, R. K. 2011. Identification and characterization of toxigenic Fusaria associated with sorghum grain mold complex in India. Mycopathologia 171:223-230.

Shotwell, O. L., Bennett, G. A., Goulden, M. L., Plattner, R. D., and Hesseltine, C. W. 1980. Survey for zearalenone, aflatoxin, and ochratoxin in U. S. grain sorghum from 1975 and 1976 crops. J. Assoc. Off. Anal. Chem. 63:922-926.
Smiley, R. W., Machado, S., Rhinhart, K. E. L., Reardon, C. L., and Wuest, S. B. 2016. Rapid quantification of soilborne pathogen communities in wheat-based long-term field experiments. Plant Dis. 100:1692-1708.

Sreenivasa, M. Y., Dass, R. S., Charith Raj, A. P., and Janardhana, G. R. 2008. PCR method for the detection of genus Fusarium and fumonisin-producing isolates from freshly harvested sorghum grains grown in Karnataka, India. J. Food Saf. 28:236-247.

Sukumaran, J., and Holder, M. T. 2010. DendroPy: A Python library for phylogenetic computing. Bioinformatics 26:1569-1571.

Tamura, K., Peterson, D., Peterson, N., Stecher, G., Nei, M., and Kumar, S. 2011. MEGA5: Molecular evolutionary genetics analysis using maximum likelihood, evolutionary distance, and maximum parsimony methods. Mol. Biol. Evol. 28:2731-2739.

Tarekegn, G., McLaren, N. W., and Swart, W. J. 2006. Effects of weather variables on grain mould of sorghum in South Africa. Plant Pathol. 55: 238-245.

Waalwijk, C., van der Heide, R., de Vries, I., van der Lee, T., Schoen, C., Costrel-de Corainville, G., Häuser-Hahn, I., Kastelein, P., Köhl, J., Lonnet, P., Demarquet, T., and Kema, G. H. J. 2004. Quantitative detection of Fusarium species in wheat using TaqMan. Eur. J. Plant Pathol. 110:481-494.

Wagacha, J. M., Oerke, E.-C., Dehne, H.-W., and Steiner, U. 2012. Colonization of wheat seedling leaves by Fusarium species as observed in growth chambers: A role as inoculum for head blight infection. Fungal Ecol. 5: 581-590.

White, T. J., Bruns, T., Lee, S., and Taylor, J. 1990. Amplification and direct sequencing of fungal ribosomal RNA genes for phylogenetics. Pages 315-322 in: PCR Protocols: A Guide to Methods and Applications. M. A. Innis, ed. Academic Press, San Diego, CA.

Wicklow, D. T., and Poling, S. M. 2009. Antimicrobial activity of pyrrocidines from Acremonium zeae against endophytes and pathogens of maize. Phytopathology 99:109-115.

Wing, N., Lauren, D. R., Bryden, W. L., and Burgess, L. W. 1993. Toxicity and trichothecene production by Fusarium acuminatum subsp. acuminatum and Fusarium acuminatum subsp. armeniacum. Nat. Toxins 1:229-234.

Zwickl, D. J. 2006. Genetic algorithm approaches for the phylogenetic analysis of large biological sequence datasets under the maximum likelihood criterion. Ph.D. dissert., The University of Texas at Austin. 